\title{
C-peptide increases the expression of vasopressin-activated calcium-mobilizing receptor gene through a $G$ protein-dependent pathway
}

\author{
Anna Maestroni, Dora Ruggieri, Giacomo Dell'Antonio ${ }^{1}$, Livio Luzi and Gianpaolo Zerbini \\ Renal Pathophysiology Laboratory, Section Nutrition-Metabolism, Department of Medicine and ${ }^{1}$ Human Pathology Division, San Raffaele Scientific \\ Institute, Milan, Italy, I-20132 \\ (Correspondence should be addressed to L Luzi; Email: luzi.livio@hsrit)
}

\begin{abstract}
Objective: Although an increasing number of reports suggest that physiological concentrations of C-peptide protect against the development of diabetic nephropathy, possibly through the modulation of $\mathrm{Na}-\mathrm{K}$ pump activity, the intracellular pathways controlled by $\mathrm{C}$-peptide are still unrecognized. C-peptide and vasopressin share similar intracellular effects including the activation of calcium influx and endothelial nitric oxide synthase. Both hormones stimulate also the activity of $\mathrm{Na}-\mathrm{K}$ pump activity. Whether the activity of C-peptide is mediated by the recently identified vasopressinactivated calcium-mobilizing receptor (VACM-1) has never been previously investigated.

Design and methods: To clarify this issue, we evaluated the effect of C-peptide on VACM-1 RNA (measured by semiquantitative RT-PCR) and protein expression (measured by immunoblotting) in human skin fibroblasts (where a specific binding of C-peptide was demonstrated) and in human mesangial cells, the cellular target of diabetic nephropathy.

Results: C-peptide-induced activation of VACM-1 was demonstrated in fibroblasts from six healthy individuals $(0.51 \pm 0.1$ vs $1.48 \pm 0.4$, arbitrary units \pm s.E., $P=0.025)$. This finding was paralleled by an increased VACM-1 protein expression (5.64 1.0 vs $8.47 \pm 1.2$, arbitrary units \pm s.E., $P=0.043)$. Similar results were confirmed in three independent cultures of human mesangial cells. VACM-1 activation in fibroblasts was insensitive to phosphatidylinositol-3-kinase inhibitor LY294002, but was inhibited by pertussis toxin, suggesting that activation of VACM-1 could be mediated by a $\mathrm{G}$ protein-coupled receptor.

Conclusions: This study demonstrates for the first time that C-peptide activates VACM-1, possibly through a $G$ protein-coupled receptor. Further studies are needed to clarify whether VACM-1 is involved in the protective effect of C-peptide against the development of diabetic nephropathy.
\end{abstract}

European Journal of Endocrinology 152 135-141

\section{Introduction}

Although for a long time thought to have no biological function, C-peptide - the product, along with insulin, of the cleavage of proinsulin $(1,2)$ - is now considered a peptide hormone, independent of insulin, possibly acting through a $\mathrm{G}$ protein-coupled membrane receptor (3-5). Recent evidence suggests that C-peptide might have a protective role in the development of diabetic complications (6-9). In particular, the finding that pancreas transplantation induces a reversal of diabetic nephropathy (10), along with the recent evidence that type 1 diabetic patients with kidney and islet transplants have a better renal prognosis than patients transplanted with kidney alone (11), has suggested the hypothesis that $\mathrm{C}$-peptide might protect the diabetic kidney from the development of nephropathy $(12,13)$. In line with these findings, we found a decreased C-peptide/creatinine ratio in the plasma of type 1 diabetic patients with nephropathy when compared with normoalbuminuric patients of similar age and duration of diabetes (14). How C-peptide can possibly exert its beneficial effect is presently unknown. In animal models $\mathrm{Na}-\mathrm{K}$ pump activity is decreased by hyperglycemia and C-peptide reverses this dysfunction (6) by modulating a not yet completely understood intracellular pathway (5). Activation of the $\mathrm{Na}-\mathrm{K}$ pump by C-peptide was also demonstrated in man (15), but whether the protection by C-peptide against diabetic complications is mediated by this mechanism remains unclear. Of interest, recent findings indicate that C-peptide increases calcium influx and stimulates endothelial nitric oxide synthase $(16,17)$, possibly through the activation of the mitogen-activated protein (MAP) kinase (18).

Among the modulators of the $\mathrm{Na}-\mathrm{K}$ pump activity, vasopressin has an established agonist role $(19,20)$ and it was also shown to increase nitric synthase 
expression levels (21). A new receptor for vasopressin, the vasopressin-activated calcium-mobilizing receptor (VACM-1) has been recently demonstrated. This receptor was first identified in the rabbit (22) and its presence was then extended also to humans (23). Human VACM-1 gene is localized on chromosome 11q22-23 (23) and is a member of the cullin gene family expressed in vascular endothelial cells and medullary collecting tubule cells (24). Although the intracellular functions of VACM-1 are not yet completely understood, a contribution of this gene to the regulation of cell signaling (25) and in particular of the MAP kinase cascade, an intracellular pathway involved in the control of $\mathrm{Na}-\mathrm{K}$ pump activity (26), has been recently demonstrated (27).

As the full comprehension of the intracellular activity of C-peptide could be of great importance toward the understanding of the pathogenesis of diabetic complications, the aim of the present study was therefore to clarify whether VACM-1 expression is modulated by C-peptide.

\section{Materials and methods}

The study was approved by the Ethics Committee of the San Raffaele Scientific Institute, Milan, Italy and informed consent was obtained from all participants. Forearm skin biopsies were obtained from six healthy non-diabetic individuals.

Synthetic human C-peptide was prepared by Primm SRL, Milan, Italy. The sequence of human C-peptide has been previously published (28). The purity of synthetic C-peptide was higher than 95\% by HPLC.

\section{Culture of fibroblasts}

A skin specimen of approximately $2 \mathrm{~mm}^{3}$ was taken by excision under local anesthesia from an avascular area of the anterior aspect of the forearm. Cells were grown to confluence in $60 \mathrm{~mm}$ culture dishes in minimum Eagle's medium (MEM) supplemented with 10\% fetal calf serum. After four passages, fibroblasts were harvested and frozen in liquid nitrogen in several aliquots. Cells were then thawed and grown as previously described (29). The experiments were performed in subconfluent cells at the sixth and seventh subculture.

\section{Experimental procedure}

Human skin fibroblasts were thawed and grown to confluence in two $90 \mathrm{~mm}$ culture dishes in the same medium as described above. When at confluence, cells were split and seeded (50000 cell per dish) in dishes containing MEM supplemented with 10\% human serum with low C-peptide concentration (see below). The medium was changed every 7 days until the cells reached subconfluence ( 2 weeks). At this point the medium was changed once again and to the dishes was added the same medium either containing or not containing $1.0 \mathrm{nmol} / \mathrm{l} \mathrm{C}$-peptide.

\section{Human serum with low C-peptide concentration}

An additive effect of C-peptide cannot be appreciated using serum from normal animals or healthy subjects $(3,4)$ because full saturation of the receptor specific for C-peptide will have occurred already in these conditions. To perform the above described experiments we therefore used a pool of sera from type 1 diabetic patients containing virtually no $\mathrm{C}$-peptide.

A blood sample $(20 \mathrm{ml})$ was obtained from ten patients affected by type 1 diabetes of more than 10 years' duration, who were informed of the experimental procedure and gave their consent. The blood sample was taken from fasting patients only if blood glucose was lower than $6.5 \mathrm{mmol} / \mathrm{l}$ according to a capillary blood glucose monitoring device. One hundred milliliters of serum were finally pooled, and laboratory analysis gave the following results: glucose: $6.0 \mathrm{mmol} / \mathrm{l}$, C-peptide: $0.036 \mathrm{nmol} / \mathrm{l}$, insulin: $120 \mathrm{pmol} / \mathrm{l}$. The serum pool was then frozen at $-80^{\circ} \mathrm{C}$.

\section{RNA extraction}

Total RNA was extracted from cultured skin fibroblasts using RNAfast reagent (Molecular System, San Diego, CA, USA) and frozen at $-80^{\circ} \mathrm{C}$. cDNA was retrotranscribed using the SuperScript II Reverse Transcriptase (Gibco, Gaithersburg, MD, USA).

\section{Semiquantitative RT-PCR}

RT-PCR primers were designed along the sequence of VACM-1 (GenBank AC NM 003478): forward primer (position 321-341), 5'-GCACGAGTACTGAGCCATCA$3^{\prime}$ and reverse primer (position 684-704) 5TGCCTTCTCAAAATTGTCCC- $3^{\prime}$, amplified portion of the sequence 321-704; size 384 bp).

In the case of $\beta$-actin: forward primer $5^{\prime}$-TGACGGGGTCACCCACACTGTGCCCATCTA-3' and reverse primer 5'-CTAGAAGCATTGCGGTGGACGATGGAGGG-3' were used for amplification of a $646 \mathrm{bp}$ fragment of human $\beta$-actin cDNA located between nucleotides 2198 and 3065 of the reported human gene sequence (GenBank AC E00829).

PCR conditions were optimized for $\mathrm{Mg}^{2+}$ concentration, primer concentration, primer annealing temperature and number of cycles for VACM-1 and $\beta$-actin cDNA amplification. VACM- 1 cDNA fragments were amplified through 32,36 and 40 cycles, and $\beta$-actin fragments through 22, 26 and 30 cycles, using the following amplification profile: $40 \mathrm{~s}$ at $94{ }^{\circ} \mathrm{C} ; 30 \mathrm{~s}$ at $59{ }^{\circ} \mathrm{C}($ VACM- 1$) / 61{ }^{\circ} \mathrm{C}\left(\beta\right.$-actin); and $50 \mathrm{~s}$ at $72^{\circ} \mathrm{C}$.

After amplification, PCR products were separated by electrophoresis on a 1\% agarose gel and were allowed 
to react with ethidium bromide for band visualization. The optical density of bands was quantified by Scion Image densitometry (National Institute of Health, Bethesda, MD, USA). Finally, expression of VACM-1 was normalized by $\beta$-actin values. The effect of C-peptide on VACM-1 expression was confirmed in fibroblasts from the same individuals as described above grown to confluence with MEM supplemented with $10 \%$ fetal calf serum and then made quiescent by substitution of the culture medium with MEM supplemented with $0.3 \%$ fetal calf serum.

\section{Immunoblotting}

Total proteins of human skin fibroblasts or human mesangial cells treated either with or without C-peptide for $24 \mathrm{~h}$ were extracted in Laemmli buffer (Tris- $\mathrm{HCl}$ $62.5 \mathrm{mmol} / \mathrm{l}, \mathrm{pH}$ 6.8, 20\% glycerol, 2\% SDS, 5\% $\beta$-mercaptoethanol) and their concentration was finally measured according to Lowry et al. (30).

Thirty-five micrograms of total proteins were electrophoresed on 7\% SDS-PAGE gels and blotted onto nitrocellulose (Schleicher \& Schuell, Dassel, Germany). Blots were then stained with Ponceau S.

Membranes were blocked for $1 \mathrm{~h}$ in TBS (Tris $(10 \mathrm{mmol} / \mathrm{l}), \mathrm{NaCl}(150 \mathrm{mmol} / \mathrm{l})), 0.1 \%$ Tween-20, $5 \%$ non-fat dry milk, pH 7.4 at $25^{\circ} \mathrm{C}$, incubated for $12 \mathrm{~h}$ with $200 \mu \mathrm{g} / \mathrm{ml}$ of a polyclonal rabbit antiVACM-1 antibody (Santa Cruz Biotechnology, Santa Cruz, CA, USA) diluted 1:200 or with a polyclonal rabbit anti- $\beta$-actin antibody (Abcam, Cambridge, MA, USA) diluted 1:1000 in TBS- $5 \%$ milk at $4{ }^{\circ} \mathrm{C}$, washed four times with TBS-0.1\% Tween-20, then incubated with a peroxidase-labeled goat anti-rabbit IgG secondary antibody diluted 1:1000 (DAKO, Glostrup, Denmark) in TBS-5\% milk, and finally washed with TBS-0.1\% Tween-20. The resulting bands were finally visualized using enhanced chemiluminescence (SuperSignal; Pierce, Rockford, IL, USA).

\section{Effect of inhibitors}

To clarify which class of receptors are involved in the C-peptide-induced activation of VACM-1, the effect of C-peptide on VACM-1 activity was evaluated either in the presence of LY294002, a strong inhibitor of phosphatidylinositol-3-kinase, one of the intracellular mediators of insulin action (31-33), or in the presence of pertussis toxin, the specific inhibitor of $\mathrm{G}$ proteincoupled receptors $(34,35)$. Three cultures of human skin fibroblasts were grown as described above and then treated for $24 \mathrm{~h}$ with or without $1.0 \mathrm{nmol} / \mathrm{l} \mathrm{C}$-peptide in the presence or absence of either $50 \mu \mathrm{mol} / \mathrm{l}$ LY294002 or $1 \mu \mathrm{g} / \mathrm{ml}$ pertussis toxin.

\section{Titration curve and time course}

Two cultures of human skin fibroblasts were grown as described above and then treated for $24 \mathrm{~h}$ with 0.01 , $0.1,1.0$ and $10 \mathrm{nmol} / \mathrm{l} \mathrm{C}$-peptide to define the titration curve of C-peptide on VACM-1 RNA expression. The time course of the effect of C-peptide on VACM-1 RNA expression was also evaluated by exposing two cultures of human skin fibroblasts to $1.0 \mathrm{nmol} / \mathrm{l} \mathrm{C}$-peptide for different incubation times $(0,2$ and $24 \mathrm{~h}$ and 7 days of incubation).

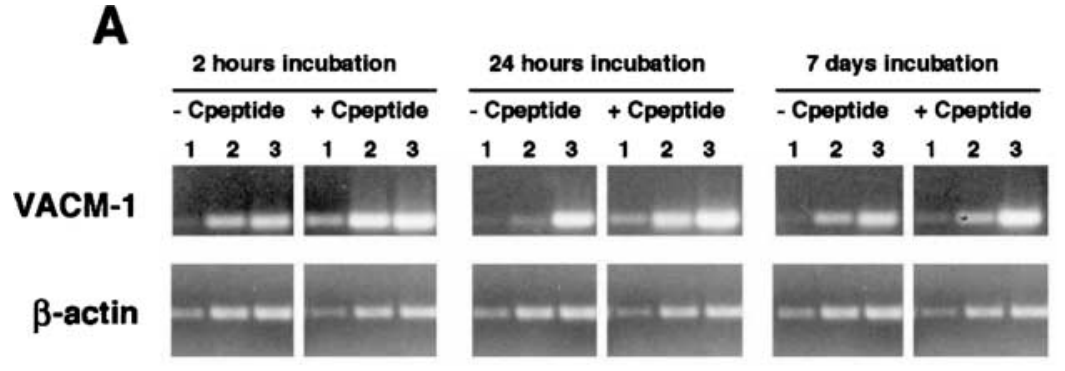

B

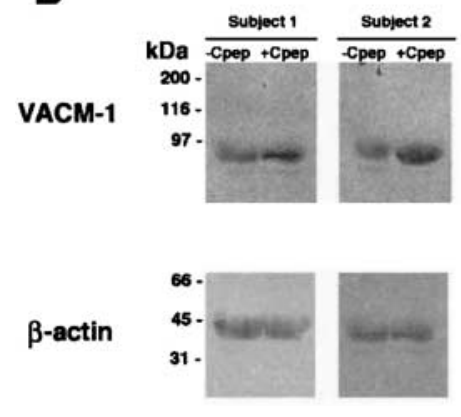

Figure 1 (A) VACM-1 RNA expression in human skin fibroblasts. Semiquantitative RT-PCR of VACM- 1 and $\beta$-actin performed in one cell culture at three different incubation times ( 2 and $24 \mathrm{~h}$ and 7 days) in the presence (+ C-peptide) or absence (-C-peptide) of $1.0 \mathrm{nmol} / \mathrm{l} \mathrm{C}$-peptide. For each incubation time three different numbers of cycles of PCR were tested: 32 (lane 1), 36 (lane 2) and 40 (lane 3) for VACM-1 and 22 (lane 1), 26 (lane 2) and 30 (lane 3 ) for $\beta$-actin. (B) VACM-1 protein expression in human skin fibroblasts. Immunoblotting of VACM-1 and $\beta$-actin performed in two independent cell cultures incubated for $24 \mathrm{~h}$ in the absence $(-$ Cpep) or presence ( + Cpep) of $1.0 \mathrm{nmol} / \mathrm{l} \mathrm{C}$-peptide. 


\section{Culture of human mesangial cells}

Human mesangial cells were obtained from renal tissue using the technique of Striker et al. (36) with minor modifications. Human kidneys not suitable for transplantation or fragments of cortical tissue excised during nephrectomies were obtained from the surgical department of our Institute. Glomeruli were isolated from the renal cortex by serial sieving, digested with collagenase (type IV, $750 \mathrm{U} / \mathrm{ml}$ ) and seeded in culture dishes. Glomerular cores were plated out in RPMI supplemented with $20 \%$ fetal calf serum, $5 \mu \mathrm{g} / \mathrm{ml}$ insulin, $5 \mu \mathrm{g} / \mathrm{ml}$ transferrin, $20 \mathrm{ng} / \mathrm{ml}$ selenium, $100 \mathrm{U} / \mathrm{ml}$ penicillin, $100 \mu \mathrm{g} / \mathrm{ml}$ streptomycin. Mesangial cell outgrowths appeared after 7-10 days in culture. Nonadherent glomeruli were removed by washing and the adherent cells were further cultured in the same medium. Cells were characterized by morphology (stellate or fusiform), and by the use of specific antibodies

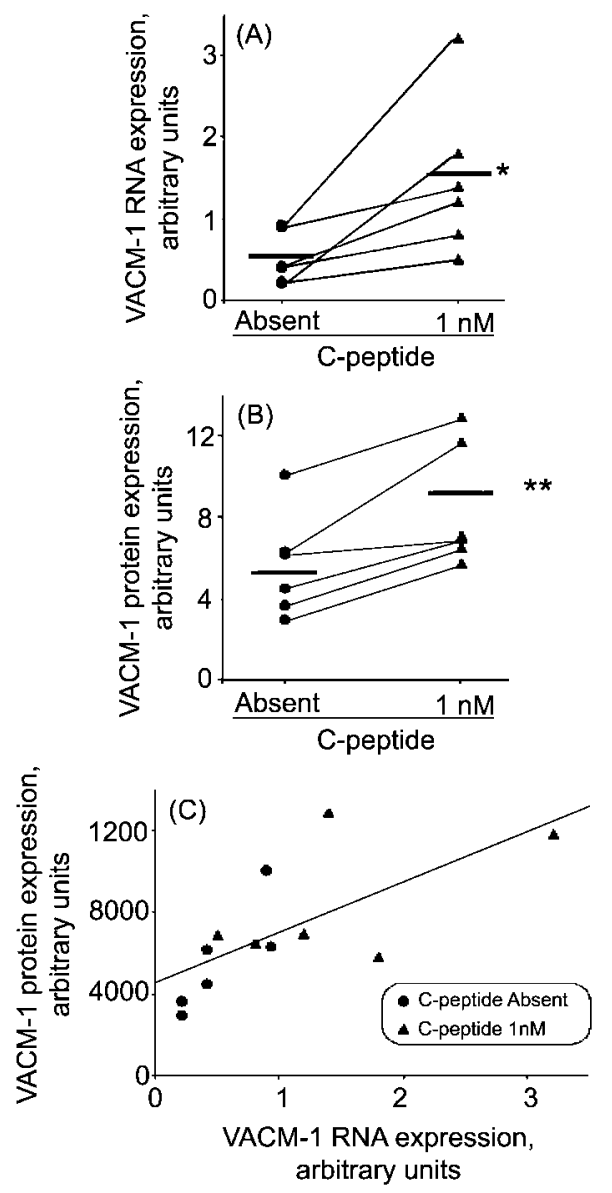

Figure 2 (A) RNA expression of VACM-1 in the absence (circles) or presence (triangles) of $1.0 \mathrm{nmol} / \mathrm{l} \mathrm{C}$-peptide for $24 \mathrm{~h}$ $\left({ }^{\star} P=0.025\right)$. Expression levels of VACM-1 are corrected for expression levels of $\beta$-actin. (B) Protein expression of VACM- 1 in the absence (circles) or presence (triangles) of $1.0 \mathrm{nmol} / \mathrm{I}$ C-peptide for $24 \mathrm{~h}\left({ }^{* \star} P=0.043\right)$. (C) Correlation between RNA and protein expression of VACM-1 in the absence (circles) or presence (triangles) of $1.0 \mathrm{nmol} / \mathrm{C}$-peptide for $24 \mathrm{~h}(P=0.01)$. (stained for smooth muscle actin and Thy-1, and not stained for cytokeratin and factor VIII), thus excluding contamination of epithelial and endothelial cells. Mesangial cells in culture were treated as previously described for human skin fibroblasts; incubation with C-peptide was stopped after $24 \mathrm{~h}$. Three independent mesangial cell lines (between the sixth and eighth subculture) were used for these experiments.

\section{Results}

\section{Human skin fibroblasts}

RNA expression of VACM-1 was evaluated in human skin fibroblasts by semiquantitative RT-PCR and, as shown in Fig. $1 \mathrm{~A}$ and Fig. 2A, C-peptide activation of VACM-1 was demonstrated in six individuals $(0.51 \pm 0.1$ vs $1.48 \pm 0.4$, arbitrary units \pm S.E., $P=0.025$ ).

To verify whether the change of RNA expression of VACM-1 was paralleled by a change of expression of its protein, we evaluated protein expression of VACM1 by immunoblotting. As a result (Fig. 1B and Fig. 2B), VACM-1 protein expression was also increased by the addition of C-peptide $(5.64 \pm 1.0$ vs $8.47 \pm 1.2$, arbitrary units \pm S.E., $P=0.043$ ) and, as shown in Fig. 2C, levels of RNA and protein expression of VACM-1 were significantly correlated to one another.
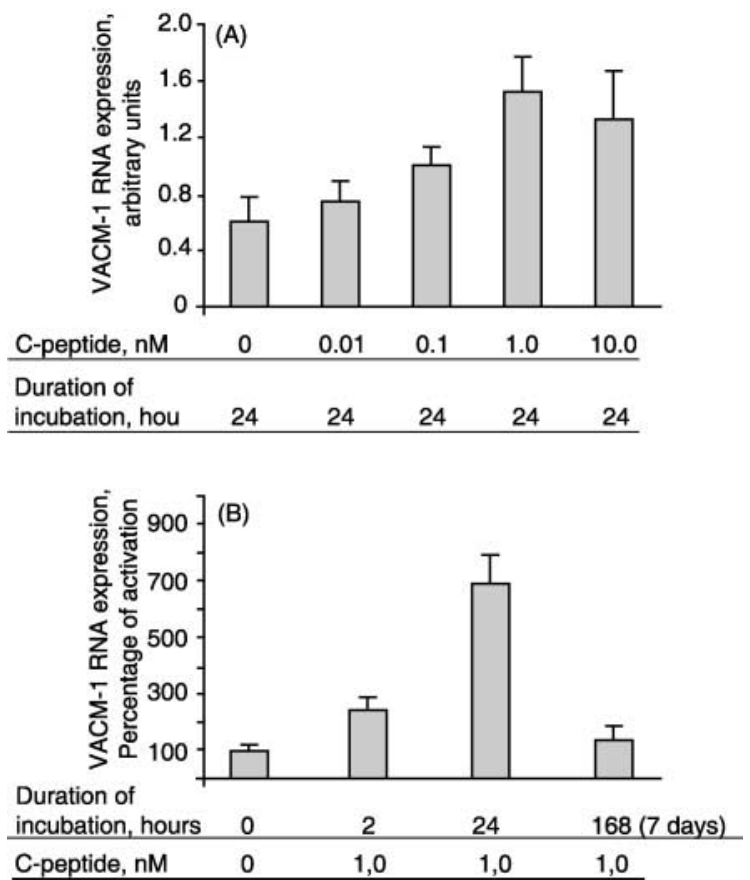

Figure 3 (A) Titration curve of the effect of $C$-peptide on the activation of VACM-1 RNA expression in two human skin fibroblasts cultures. Bars show mean and S.E. (B) Time course of the effect of C-peptide on the activation of VACM-1 RNA expression in two human skin fibroblasts cultures. Results are expressed as percentage of activation where the control (time zero, no C-peptide) is considered to be equal to $100 \%$. 


\section{Titration curve and time course}

As shown in Fig. 3A and B, incubation of human skin fibroblasts with $1.0 \mathrm{nmol} / \mathrm{l}$ C-peptide for $24 \mathrm{~h}$ was shown to induce the larger increase of VACM-1 RNA expression and was therefore used as the standard incubation procedure to test the effect of $\mathrm{C}$-peptide on VACM-1 gene and protein expression.

\section{Effect of inhibitors of phosphatidylinositol-3- kinase and G proteins on VACM-1 expression}

As shown in Fig. 4A and B, C-peptide was confirmed to activate VACM-1 expression $(0.84 \pm 0.2$ vs $1.38 \pm 0.1$, arbitrary units \pm S.E., $P<0.05, n=3)$. This phenomenon was not affected by the addition of $50 \mu \mathrm{mol} / \mathrm{l}$ phosphatidylinositol-3-kinase inhibitor LY294002 $(0.71 \pm 0.03$ vs $1.12 \pm 0.07, P<0.05, n=3)$ and was instead blunted by the addition of $1 \mu \mathrm{g} / \mathrm{ml}$ pertussis toxin, the specific inhibitor of $\mathrm{G}$ proteins $(0.89 \pm 0.09$ vs $0.70 \pm 0.1, P=\mathrm{NS}, n=3)$.

\section{Human mesangial cells}

The effect of C-peptide on VACM-1 gene and protein expression was then verified in human mesangial cells. As a result, in three independent mesangial cell cultures, VACM-1 RNA expression (0.57 \pm 0.2 vs $1.13 \pm 0.3$, arbitrary units \pm s.E., $P=0.024$, Fig. $5 \mathrm{~A})$ and expression of VACM-1 protein evaluated by immunoblotting $(7.10 \pm 1.5$ vs $15.49 \pm 3.22$, arbitrary units \pm s.E., $P=0.006$, Fig. $5 \mathrm{~B}$ ) were significantly increased by the addition of C-peptide $(1.0 \mathrm{nmol} / \mathrm{l}$ for $24 \mathrm{~h}$ ), in line with the results previously shown for human skin fibroblasts.

\section{Discussion}

The results of the present study demonstrate for the first time that C-peptide modulates VACM-1 gene expression in human skin fibroblasts and mesangial cells.

Prompted by the evidence that C-peptide $(6,15)$ and vasopressin $(19,20)$ are both established stimuli for the $\mathrm{Na}-\mathrm{K}$ pump we focused our attention on VACM-1, showing by semiquantitative RT-PCR and immunoblotting that C-peptide increases both VACM-1 gene and protein expression.

The human skin fibroblast is one of the cells where a specific C-peptide binding has been suggested (4) and the evidence that C-peptide increases VACM-1 gene and protein expression in the six cultures of fibroblasts considered for the study strongly indicates this receptor as a possible mediator of C-peptide activity. On the other hand, the finding that also in the human mesangial cell C-peptide exerts a similar effect on VACM-1 expression is in line with the possibility that the $\mathrm{C}$-peptide receptor might be present also in these cells.

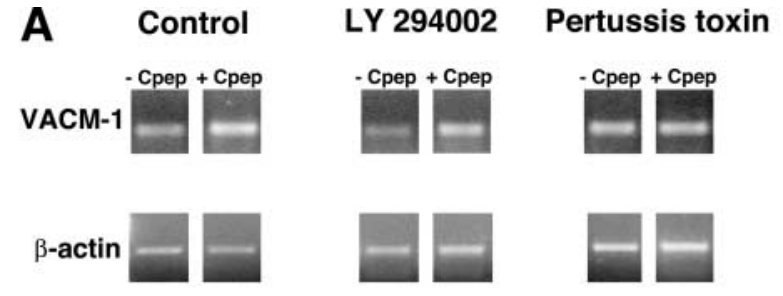

B
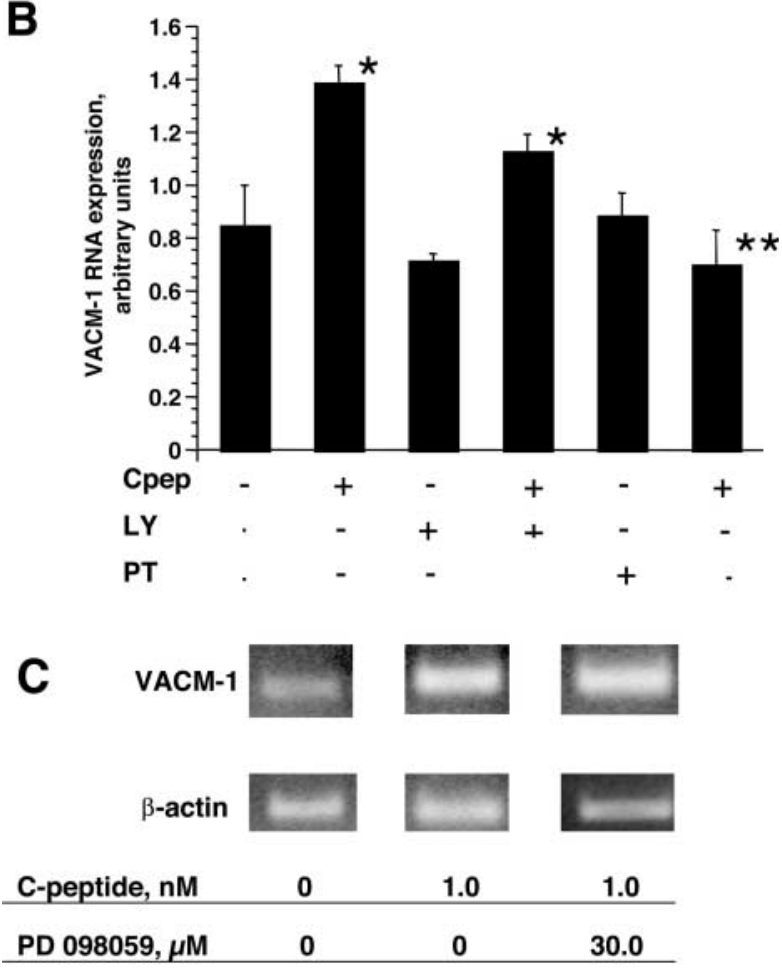

Figure 4 (A) Effect of inhibitors on VACM-1 RNA expression in human skin fibroblasts. Semiquantitative RT-PCR of VACM-1 and $\beta$-actin performed in one cell culture after $24 \mathrm{~h}$ of incubation with (+C-pep) or without (-C-pep) $1.0 \mathrm{nmol} / \mathrm{l} \mathrm{C}$-peptide and in the presence or absence of either $50 \mu \mathrm{mol} / \mathrm{l}$ phosphatidylinositol-3-kinase inhibitor LY294002 or $1 \mu \mathrm{g} / \mathrm{ml}$ G protein inhibitor pertussis toxin. (B) Mean RNA expression of VACM-1 of three independent cultures of human skin fibroblasts treated for $24 \mathrm{~h}$ with or without $1.0 \mathrm{nmol} / \mathrm{l} \mathrm{C}$-peptide in the presence or absence of either $50 \mu \mathrm{mol} / \mathrm{L} \mathrm{LY} 294002$ or $1 \mu \mathrm{g} / \mathrm{ml}$ pertussis toxin. ${ }^{\star} P<0.05$ when compared with the same cells grown without $\mathrm{C}$-peptide, ${ }^{\star *} P=\mathrm{NS}$ when compared with the same cells grown without $\mathrm{C}$-peptide.

Interestingly, the evidence that the major intracellular effects of C-peptide, i.e. increased calcium influx (16) and activation of the endothelial nitric oxide synthase (17) - paralleled by the in vivo finding that C-peptide in type 1 diabetic patients leads to a redistribution in skin microvascular blood flow levels (37) - are similar to the ones induced by vasopressin $(21,38)$ supports indirectly the hypothesis that at least part of C-peptide activity might be mediated by VACM-1 activation.

Despite several arguments confirming the existence of a specific C-peptide receptor (4), its responsible gene has not yet been identified, thus hampering the 


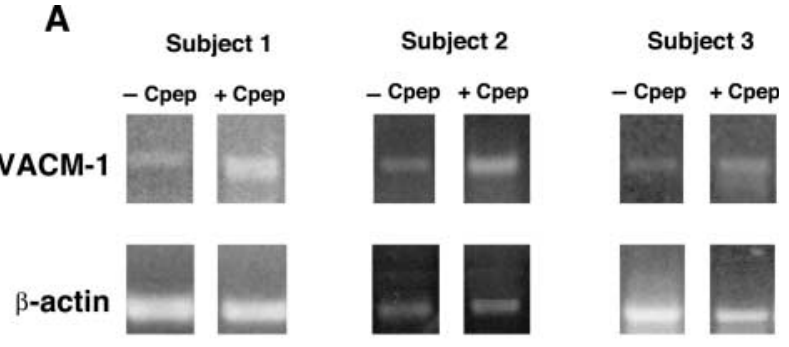

B

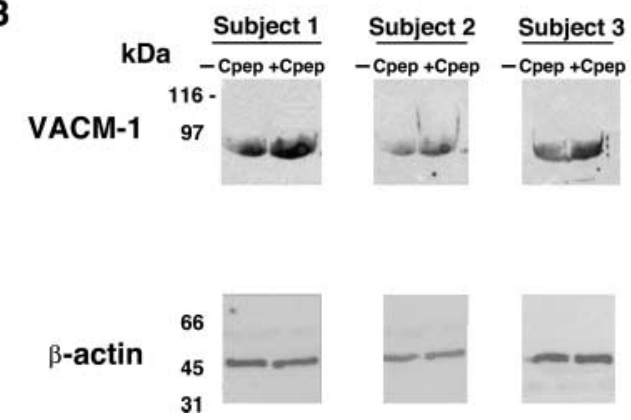

Figure 5 (A) VACM-1 RNA expression in human mesangial cells. Semiquantitative RT-PCR of VACM-1 and $\beta$-actin performed in three independent cell cultures after $24 \mathrm{~h}$ of incubation in the presence (+C-pep) or absence (-C-pep) of $1.0 \mathrm{nmol} / \mathrm{l} \mathrm{C-peptide.}$ (B) VACM-1 protein expression in human mesangial cells. Immunoblotting of VACM-1 and $\beta$-actin performed in three independent cell cultures incubated for $24 \mathrm{~h}$ in the absence (- Cpep) or presence (+ Cpep) of $1.0 \mathrm{nmol} / / \mathrm{l}$ C-peptide.

possibility of definitely clarifying which cells express this receptor and at the same time of defining its role in mediating C-peptide effect. Our findings, however, by demonstrating that pertussis toxin, but not LY294002, inhibits the C-peptide-induced activation of VACM-1 expression are in line with previous studies suggesting that $\mathrm{C}$-peptide activity might be mediated by a $\mathrm{G}$ protein-coupled receptor $(3,4)$.

Mesangial cells represent the established cellular target of diabetic nephropathy (39). The evidence that C-peptide activates VACM-1 expression also in these cells might suggest that this pathway could be directly involved in the beneficial effect of C-peptide against the development of diabetic nephropathy. The evaluation in human mesangial cell of the effect of VACM-1 activation on $\mathrm{Na}-\mathrm{K}$ pump activity and in parallel on the production of matrix components (such as collagens and fibronectin), whose overproduction usually goes along with the development of diabetic nephropathy, could be of great help toward the comprehension of the cellular mechanisms underlying the pathogenesis of this complication.

In vitro growing cells tend to de-differentiate and the original phenotype is progressively lost (40). To avoid this problem we studied fibroblasts and mesangial cells at an early culture passage (between the sixth and seventh subculture), in line with previous reports (36).

Finally, the recent report from the Diabetes Control and Complication Trial that patients with sustained C-peptide secretion levels have a lower incidence of diabetic complications (41) can be explained by a protective effect induced by the parallel remnant secretion of insulin but also, as suggested by the authors as well, by an independent beneficial effect of C-peptide by itself.

In conclusion, this study demonstrates that in both human skin fibroblasts and mesangial cells C-peptide exerts at least some of its effects through the modulation of the expression of the VACM-1 gene. VACM-1 activation was maintained after phosphatidylinositol3-kinase inhibition and blunted by pertussis toxin, the specific inhibitor of $\mathrm{G}$ protein-coupled receptor, in line with the hypothesis that this intracellular pathway mediates C-peptide activity. Because of the small number of cell cultures used in these experiments, the evidence that semiquantitative RT-PCR allows only an approximate quantification of mRNA and the lack of controls done using an inactive form of C-peptide, our results have to be considered preliminary and further investigations will now be needed to confirm this hypothesis and to clarify whether VACM-1 activation is involved in the protective effect of C-peptide against the development of diabetic nephropathy.

\section{Acknowledgements}

We are indebted to Laboratori Guidotti SPA, Pisa, Italy for kindly providing C-peptide.

\section{References}

1 Steiner D, Cunningham D, Spigelman L \& Aten B. Insulin biosynthesis: evidence for a precursor. Science $1967157697-700$.

2 Rubenstein A, Clark J, Melani F \& Steiner D. Secretion of proinsulin, C-peptide by pancreatic beta cells and its circulation in blood. Nature 1969224 697-699.

3 Wahren J, Ekberg K, Johansson J, Henriksson M, Pramanik A, Johansson BL, Rigler R \& Jornvall $\mathrm{H}$. Role of C-peptide in human physiology. American Journal of Physiology. Endocrinology and Metabolism 2000278 E759-E768.

4 Rigler R, Pramanik A, Jonasson P, Kratz G, Jansson OT, Nygren P, Stahl S, Ekberg K, Johansson B, Uhlen S, Uhlen M, Jornvall H \& Wahren J. Specific binding of proinsulin C-peptide to human cell membranes. PNAS 199996 13318-13323.

5 Johansson J, Ekberg K, Shafqat J, Henriksson M, Chibalin A, Wahren J \& Jornvall H. Molecular effects of proinsulin C-peptide. Biochemical and Biophysical Research Communications 2002295 1035-1040.

6 Ido Y, Vindigni A, Chang K, Stramm L, Chance R, Heath WF, DiMarchi RD, DiCera E \& Williamson JR. Prevention of vascular and neural dysfunction in diabetic rats by C-peptide. Science $1998277563-566$.

7 Sjoquist M, Huang W \& Johansson B-L. Effects of C-peptide on renal function at the early stage of experimental diabetes. Kidney International $1998 \mathbf{5 4} 758-764$.

8 Johansson BL, Borg K, Fernqvist-Forbes E, Kernell A, Odergren T \& Wahren J. Beneficial effects of C-peptide on incipient 
nephropathy and neuropathy in patients with Type 1 diabetes mellitus. Diabetic Medicine 200017 181-189.

9 Ekberg K, Brismar T, Johansson BL, Jonsson B, Lindstrom P \& Wahren J. Amelioration of sensory nerve dysfunction by C-peptide in patients with type 1 diabetes. Diabetes 200352 $536-541$.

10 Fioretto P, Steffes MW, Sutherland DER, Goetz FC \& Mauer M. Reversal of lesions of diabetic nephropathy after pancreas transplantation. New England Journal of Medicine 1998339 $69-75$.

11 Fiorina P, Folli F, Zerbini G, Maffi P, Gremizzi C, Di Carlo V, Socci C, Bertuzzi F, Kashgarian $M$ \& Secchi A. Islet transplantation is associated with improvement of renal function among uremic patients with type I diabetes mellitus and kidney transplants. Journal of the American Society of Nephrology $2003142150-2158$.

12 Luzi L. Pancreas transplantation and diabetic complications. New England Journal of Medicine 1998339 115-117.

13 Shapiro AMJ. Islet transplants and impact on secondary diabetic complications: does C-peptide protect the kidney? Journal of the American Society of Nephrology 200314 2214-2216.

14 Zerbini G, Mangili R \& Luzi L. Higher post-absorptive C-peptide levels in Type 1 diabetic patients without renal complications. Diabetic Medicine 1999161048.

15 Forst T, De La Tour DD, Kunt T, Pfutzner A, Goitom K, Pohlmann T, Schneider S, Johansson BL, Wahren J, Lobig M, Engelbach M, Beyer J \& Vague P. Effects of proinsulin C-peptide on nitric oxide, microvascular blood flow and erythrocyte Na, K-ATPase activity in diabetes mellitus type I. Clinical Science $2000 \mathbf{9 8}$ $283-290$.

16 Shafqat J, Juntti-Berggren L, Zhong Z, Ekberg K, Kohler M, Berggren PO, Johansson J, Wahren J \& Jornvall H. Proinsulin $\mathrm{C}$-peptide and its analogues induce intracellular $\mathrm{Ca}^{2+}$ increases in human renal tubular cells. Cellular and Molecular Life Sciences 200259 1185-1189.

17 Wallerath T, Kunt T, Forst T, Closs EI, Lehmann R, Flohr T, Gabriel M, Schafer D, Gopfert A, Pfutzner A, Beyer J \& Forstermann U. Stimulation of endothelial nitric oxide synthase by proinsulin C-peptide. Nitric Oxide 2003 9 95-102.

18 Kitamura T, Kimura K, Makondo K, Furuya DT, Suzuki M, Yoshida T \& Saito M. Proinsulin C-peptide increases nitric oxide production by enhancing mitogen-activated protein-kinasedependent transcription of endothelial nitric oxide synthase in aortic endothelial cells of Wistar rats. Diabetologia 200346 1698-1705.

19 Blot-Chabaud M, Coutry N, Laplace M, Bonvalet J \& Farman N. Role of protein phosphatase in the regulation of Na-K-ATPase by vasopressin in the cortical collecting duct. Journal of Membrane Biology 1996153 233-239.

20 Feraille E, Mordasini D, Gonin S, Deschenes G, Vinciguerra M, Doucet A, Vandewalle A, Summa V, Verrey F \& Martin PY. Mechanism of control of Na,K-ATPase in principal cells of the mammalian collecting duct. Annals of the New York Academy of Sciences 2003986 570-578.

21 Martin PY, Bianchi M, Roger F, Niksic L \& Feraille E. Arginine vasopressin modulates expression of neuronal NOS in rat renal medulla. American Journal of Physiology. Renal Physiology 2002 283 F559-F568.

22 Burnatowska-Hledin M, Spielman WS, Smith WL, Shi P, Meyer JM \& Dewitt DL. Expression cloning of an AVP-activated calciummobilizing receptor from rabbit kidney medulla. American Journal of Physiology. Renal Physiology 1995268 F1198-F1210.

23 Byrd PJ, Stankovic T, McConville CM, Smith AD, Cooper PR \& Taylor AMR. Identification and analysis of expression of human VACM-1, a cullin gene family member located on chromosome 11q22-23. Genome Research 19977 2-6.

24 Burnatowska-Hledin M, Lazdins IB, Listenberger L, Zhao P, Sharangpani A, Folta V \& Card B. VACM-1 receptor is specifically expressed in rabbit vascular endothelium and renal collecting tubule. American Journal of Physiology. Renal Physiology 1999 276 F199-F209.
25 Burnatowska-Hledin M, Zhao P, Capps B, Poel A, Parmelee K, Mungall C, Sharangpani A \& Listenberger L. VACM-1, a cullin gene family member, regulates cellular signaling. American Journal of Physiology. Cell Physiology 2000279 C266-C273.

26 Isenovic ER, Jacobs DB, Kedees MH, Sha Q, Milivojevic N, Kawakami K, Gick G \& Sowers JR. Angiotensin II regulation of the Na pump involves the phosphatidylinositol-3 kinase and p42/44 mitogen-activated protein kinase signaling pathways in vascular smooth muscle cells. Endocrinology $2004 \mathbf{1 4 5}$ 1151-1160.

27 Van Dort C, Zhao P, Parmelee K, Capps B, Poel A, Listenberger L, Kossoris J, Wasilevich B, Murrey D, Clare P \& BurnatowskaHledin M. VACM-1, a cul-5 gene, inhibits cellular growth by a mechanism that involves MAPK and p53 signaling pathways. American Journal of Physiology. Cell Physiology 2003285 C1386-C1396.

28 Oyer PE, Cho S, Peterson JD \& Steiner DF. Studies on human proinsulin. Isolation and amino acid sequence of the human pancreatic C-peptide. Journal of Biological Chemistry 1971246 1375-1386.

29 Zerbini G, Mangili R, Gabellini D \& Pozza G. Modes of operation of an electroneutral $\mathrm{Na} / \mathrm{Li}$ counter transport in human skin fibroblasts. American Journal of Physiology. Cell Physiology 1997 272 C1373-C1379.

30 Lowry OH, Rosenbrough AL, Farr AL \& Randall RJ. Protein measurements with the Folin phenol reagent. Journal of Biological Chemistry 1951193 265-275.

31 Sanchez-Margalet V, Goldfine ID, Vlahos CJ \& Sung CK. Role of phosphatidylinositol-3-kinase in insulin receptor signaling: studies with inhibitor, LY294002. Biochemical and Biophysical Research Communications 1994204 446-452.

32 Sanchez-Margalet V. Stimulation of glycogen synthesis by insulin requires S6 kinase and phosphatidylinositol-3-kinase in HTC-IR cells. Journal of Cellular Physiology 2000182 182-188.

33 Ruderman NB, Kapeller R, White MF \& Cantley LC. Activation of phosphatidylinositol 3-kinase by insulin. PNAS $1990 \quad \mathbf{8 7}$ 1411-1415.

34 Becker EL, Kanaho Y \& Kermode JC. Nature and functioning of the pertussis toxin-sensitive $\mathrm{G}$ protein of neutrophils. Biomedical Pharmacotherapy $198741289-297$.

35 Martinez-Olmedo MA \& Garcia Sainz JA. Direct action of pertussis toxin in isolated hamster fat cells. European Journal of Pharmacology 198499 115-118.

36 Striker GE, Killen PD \& Farin FM. Human glomerular cells in vitro: isolation and characterization. Transplantation Proceedings 1980 $1288-99$.

37 Forst T, Kunt T, Pohlmann T, Goitom K, Engelbach M, Beyer J \& Pfutzner A. Biological activity of C-peptide on the skin microcirculation in patients with insulin-dependent diabetes mellitus. Journal of Clinical Investigation $19981012036-2041$.

38 Lidofsky SD, Xie MH, Sostman A, Scharschmidt BF \& Fitz JG. Vasopressin increases cytosolic sodium concentration in hepatocytes and activates calcium influx through cation-selective channels. Journal of Biological Chemistry $1993 \mathbf{2 6 8}$ $14632-14636$.

39 Steffes MW, Osterby R, Chavers B \& Mauer SM. Mesangial expansion as a central mechanism for loss of kidney function in diabetic patients. Diabetes 198938 1077-1081.

40 Khorramizadeh MR, Tredget EE, Telasky C, Shen Q \& Ghahary A. Aging differentially modulates the expression of collagen and collagenase in dermal fibroblasts. Molecular and Cellular Biochemistry 1999194 99-108.

41 Steffes MW, Sibley S, Jackson M \& Thomas W. Beta-cell function and the development of diabetes-related complications in the Diabetes Control and Complications Trial. Diabetes Care 2003 $26832-836$.

Received 3 August 2004

Accepted 5 October 2004 